6. Genetic diversity and population structure analysis of synthetic and bread wheat accessions in Western Siberia / M. Bhatta [et al.] // Journal of applied genetics. - 2019. - V. 60 (3-4), P. 283-289.

7. Kihara H. Discovery of the DD analyser, one of the ancestors of Triticum vulgare / H. Kihara // Agric. Hort. - 1944. - V.19. - P. 889-890.

8. McFadden, E.S., Sears, E.R. The artificial synthesis of Triticum spelta / E.S. McFadden, E.R. Sears // Rec. Genet. Soc. Am. - 1944. - V.13. - P. 26-27.

\title{
Молекулярно-генетические основы для направленной селекции на содержание полифенольных соединений в зерне ячменя
}

Шоева О.Ю. ${ }^{1 *}$, к.б.н., с.н.с., Стрыгина К.В. ${ }^{2}$, Глаголева А.Ю. ${ }^{1}$, Гордеева Е.И. ${ }^{1}$, Вихорев А.В. ${ }^{1}$, Кукоева T.В. ${ }^{1}$, Хлесткина Е.К. ${ }^{1,2}$

${ }^{1}$ Института циитологии и генетики СО РАН (ИЦиГ СО РАН), Новосибирск, Россия,

${ }^{2}$ Всероссийского института генетических ресурсов растений имени Н.И. Вавилова (ВИР), Санкт-Петербург, Россия.

*e-mailolesya_ter@bionet.nsc.ru

Состав и количество полифенольных соединений в зерне ячменя определяют его изелевое использование. Направленное создание новых сортов с заданными паттернами полифенольных соединений невозможно без знаний об их синтезе и его генетической регуляция. В представленной работе были идентифицированы гень, контролирующие биосинтез антоциановых пигментов и проантоцианидинов в зерне ячменя и установлены особенности их функционирования. Полученные данные используются в селекции на содержание и состав полифенольных соединений в зерне ячменя.

Ключевые слова: Hordeum vulgare, антоцианы, проантоциианидины, меланинь функциональное питание, пивоварение, маркер-ориентированная селекция.

\section{Molecular-genetic basis for directed breeding for polyphenol content in barley grain}

Shoeva O.Yu., Senior Researcher, the FRC Institute of Cytology and Genetics SB RAS, Novosibirsk, Lavrentjeva ave., 10,*e-mail: olesya_ter@bionet.nsc.ru

The content and composition of polyphenolic compounds in barley grain determines its objective application. The targeted creation of new varieties of barley with given patterns of polyphenolic compounds is impossible without knowledge of their synthesis and its regulation. In the presented study, the regulatory genes that control synthesis of anthocyanin pigments and proanthocyanidins in barley grain 
were identified, and the features of their functioning were established. The data obtained are used in breeding for the content of polyphenolic compounds in barley grain.

Keywords: Hordeum vulgare, anthocyanidins, proanthocyanidins, melanins, functional food, brewing, marker-assisted breeding.

К полифенольным соединениям растений относятся гидролизуемые танины, меланины, и фенилпропаноиды (флавоноиды, лигнин, конденсированные танины). Они выполняют важные функции у растений: регулируют их рост и развитие, играют защитную роль при различных типах стресса, участвуют в поддержании состояния покоя семян [1]. В зерне ячменя (Hordeum vulgare L.) могут синтезироваться различные группы полифенольных соединений (см. рисунок).

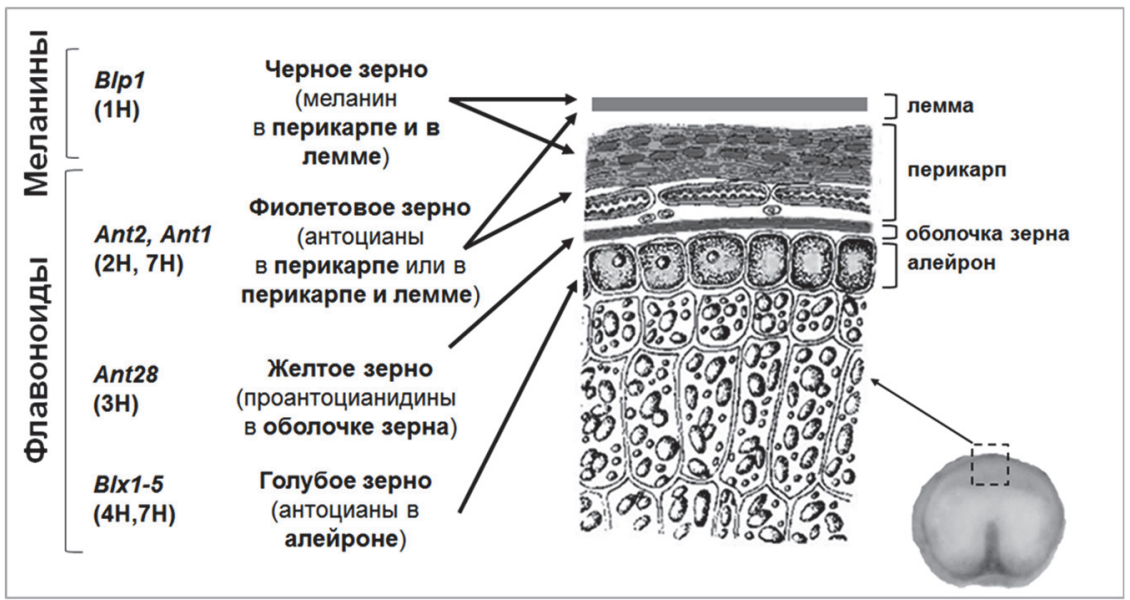

Рисунок. Гены, контролирующие синтез полифенольных соединений в различных частях зерновки ячменя, и их хромосомная локализация. Полифенольные соединения, определяющие окраску зерна, и их локализация в частях зерновки указаны в скобках.

Их состав и количество имеют важное практическое значение и определяют целевое использование зерна. Антоциановые пигменты, которые могут синтезироваться в перикарпе (под контролем генов Ant1 и Ant2) и алейроновом слое зерна (Blxl-5), придавая ему фиолетовую и голубую окраски, соответственно, являются перспективными компонентами функционального питания [2]. Полимерные флавоноидные соединения проантоцианидины (Ant28) синтезируются в оболочке зерна ячменя, при окислении определяя красно-коричневую его окраску. Данные соединения вызывают колло- 
идное помутнение пива при хранении, являясь нежелательными в пивоваренных сортах ячменя [3]. Меланины (Blpl) могут накаливаться в цветковых чешуях и в перикарпе. Данный тип пигментов рассматривается в качестве сырья для получения антиоксидантов, противостарителей, ингибиторов радикальных реакций, сорбентов, биостимуляторов [4,5]. Для направленного создания новых сортов ячменя с заданными паттернами полифенольных соединений в зерне необходимы знания о генетическом контроле их синтеза и его регуляции.

Целью исследования являлось определение молекулярных функций генов, определяющих тканеспецифическое накопление флавоноидных пигментов в зерне ячменя. В работе использовались полученные с помощью радиационного и химического мутагенеза безантоциановые и/или безпроантоцианидиновые Ant (anthocyanin-less) мутантные [6] и почти-изогенные линии ячменя, содержание различные аллели регуляторных генов, контролирующих синтез антоцианов [7].

На основе данных сравнительного картирования, а также транскрипционного анализа структурных генов, кодирующих ферменты биосинтеза антоцианов, было показано, что локус Ant1 (картирован на хромосоме 7HS) кодирует транскрипционный фактор (ТФ) семейства MYB, необходимый для активации экспрессии структурных генов в листовом влагалище растений ячменя [8]; ген Ant2 (2HL) кодирует ТФ типа bHLH, необходим совместно с Ant1 для активации биосинтеза антоцианов в перикарпе зерна $[9,10]$. Локус Ant13 ко-локализуется с геном $W D 40$ в длинном плече хромосомы 6HL и участвует в активации транскрипции структурных генов в листовом влагалище и в зерне ячменя, где он принимает участие в синтезе антоцианов и проантоцианидинов, соответственно. У мутантов ant13 были выявлены однонуклеотидные нонсенс и миссенс мутации в нуклеотидных последовательностях данного гена. Выявленные мутации позволяют разработать молекулярные маркеры к нефункциональным аллелям гена $W D 40$ и использовать их в селекции на отсутствие проантоцианидинов в зерне.

Секвенирование генов-кандидатов для локусов Ant1 и Ant2 у почти изогенных линий, отличающихся окраской перикарпа, выявило различия в промоторных областях этих генов, которые предположительно связаны с различной их функциональной активностью в окрашенном и неокрашенном зерне. Выявленные отличия были использованы для разработки диагностических маркеров для с создания почти-изогенных линий ячменя с различными комбинациями доминантных и рецессивных аллей этих генов [10]. Анализ экспрессии структурных генов в полученных линиях показал, что транскрипция структурного гена $A n s$, кодирующего антоцианидинсинтазу (ANS), зависит от наличия доминантных аллелей как Ant1, так и Ant2. Поскольку анализ безантоциановых мутантов показал, что локусы Ant1, Ant2 и Ant5 совместно 
контролируют реакцию превращения лейкоантоцианидинов в антоцианидины, катализируемую ANS [6], ген Ans был предложен в качестве гена-кандидата для локуса Ant5. Секвенирование гена Ans у мутантов ant5 и их родительских сортов выявило SNP, вызывающие стоп-кодоны и аминокислотные замены, нарушающие функционирование белка. С помощью полученных линий также были установлены регуляторные взаимоотношения между генами Ant1 и Ant2 по типу регуляторной петли с положительной обратной связью.

Используя полученные данные о генах, контролирующих биосинтез флавоноидов, и отличиях между доминантными и рецессивными аллелями этих генов мы можем направленно создавать новые сорта с заданными паттернами антоциановых и проантоцианидиновых соединений в зерновках ячменя.

Благодарности: Работа выполнена в рамках проекта КГЦ № 075-152019-1662, при частичной поддержке гранта РФФИ №19-016-00140 и Visby Scholarship Program №25896/2018.

\section{Список литературы}

1. Khlestkina E.K. The adaptive role of flavonoids: emphasis on cereals // Cereal Research Communication. 2013;41:185-198.

2. Calderaro A., Barreca D., Bellocco E., Smeriglio A., Trombetta D., Laganà G. Colored phytonutrients: role and applications in the functional foods of anthocyanins. Phytonutrients in food: From traditional to rational usage. Eds. S. M. Nabavi, I. Suntar, D. Barreca, H. Khan. Woodhead Publishing, 2020:177-195.

3. von Wettstein D. From analysis of mutants to genetic engineering // Annual Review of Plant Biology. 2007;58:1-19.

4. Gracheva N.V., Zheltobryukhov V.F. Sorbtion properties of sunflower husk melanins // Pharmaceutical Chemistry Journal. 2019;53(4):337-341.

5. Kablov V.F., Novopoltseva O.M., Gracheva N.V., Zheltobryukhov V.F., Dao P.K. Prospects of application of melanins as antiaging agents in elastomer compositions // Vietnam Journal of Chemistry. 2019;57(2):255-260.

6. Jende-Strid B. Genetic control of flavonoid biosynthesis in barley // Hereditas. 1993;119:187-204.

7. Druka et al. 2011.

8. Shoeva O.Y., Kukoeva T.V., Börner A., Khlestkina E.K. Barley Ant1 is a homolog of maize $C 1$ and its product is part of the regulatory machinery governing anthocyanin synthesis in the leaf sheath // Plant Breeding. 2015; 134:400-405.

9. Shoeva O.Y., Mock H.P., Kukoeva T.V., Börner A., Khlestkina E.K. Regulation of the flavonoid biosynthesis pathway genes in purple and black grains of Hordeum vulgare. PloS one. 2016;11(10).

10. Gordeeva E.I., Glagoleva AY, Kukoeva TV, Khlestkina EK, Shoeva OY. 2019. Purple-grained barley (Hordeum vulgare L.): marker-assisted development of NILs for investigating peculiarities of the anthocyanin biosynthesis regulatory network // BMC Plant Biology. 19(Suppl 1):52. 